\title{
Another Minority's Role in Medicine: The Armenians
}

By Erwin H. Ackerknecht

When I discussed a few years ago the role and accomplishments of three persecuted minorities in medicine during the 19th century ${ }^{1} \mathrm{I}_{\text {concluded }}$ "Their role in science and industry is easier explained by their minority role, a role, which has condemned them to centuries of persecution and suffering. Suffering does by no means always produce achievement. Yet it did in the case of our three groups."

As an illustration of this sceptic statement I would like to examine the fate of another famous minority, the Armenians. As the Jewish Encyclopedia rightly states (vol. III, p. 475, Jerusalem 1971) "The Armenian diaspora is the closest historical parallel to the Jewish diaspora and a comparison of the two reveals much in common. Both suffered loss of statehood and underwent the process of urbanisation. They traveled similar migrationary routes, adopted similar trades, received charters of privileges and established communal organisations. They also faced similar problems of assimilation, survival and accusations made against her dispersed people and underwent similar psychological stresses." We might add: both were in the first half of the 20 th century victims of an attempted "final solution". In 1915 etc. the Turks killed one third of all living Armenians (ca. 1.5 millions) helped by Kurds. In 1942 etc. the Germans killed one third of all living Jews (ca. 6 millions).

While the history of the Jews is relatively well known, being also to a large part reported in our Bible, that of the Armenians is little known in the West. I therefore survey it here very shortly ${ }^{2}$. The Armenian plateau where at least for over 2500 years the majority of the Armenians lived is located in Western Asia between the Black and the Caspian sea, south of the Caucasus around the famous Ararat mountain, which lays not far from Erivan and the sources of Euphrat and Tigris.

At what time the indogermanic Armenians immigrated from the West is not clear. They are mentioned first as a small kingdom in the great Persian empire of Cyrus and Darius in the 6th century BC. Xenophon and his Greak mercenaries crossed their region in the course of his anabasis in $400 \mathrm{BC}$ : after the victory of Alexander of Makedonia (333 BC), they came under strong Greek influence, also culturally. Like all small states located between two 
giants they achieved a certain independance only in maneuvering between the two, in their case mostly Rome and Persia.

In $301 \mathrm{AD}$ they became christianised before any other state and have remained Christian with their own special church, even under Arabic and Turk domination, up to this day. Unlike others they resisted attempts of conversion to Zoroaster as well as to Mahomet. In 406 they also developed their own alphabet and script, which helped to perpetuate their language, culture, and their own periodisation, taking $551 \mathrm{AD}$ as their year one.

In the Byzantine empire no less than 15 Armenians (often Ex-Generals) ${ }^{3}$ occupied the throne between 582 and 1028. The Armenians were under the rule of Arab Kalifs after 645. The highest degree of relative independance and cultural flowering they probably achieved under the Bagratide Kings (885-1045). For a while they were close to the Christian kingdom of Jerusalem. Like the whole region they suffered heavily from the Mongol invasions of Dschingis Khan in 1207 and Tamerlan in 1287.

The Armenians transfered after 1080 their kingdom to Cilicia where it still existed till the end of the 14th century when most of them came unter Turkish domination. The Turks accomplished the work of submission of former turkoman invaders (e. g. Seldschuks 1064, Mamelouks 1260). Parts of Armenia remained Persian, Arab as well as Ottoman-Turkish rulers, though Mohamedans, were then still tolerant and even favored Armenian Immigration. Armenians were respected for their craftmanship, their business acumen, their literacy and their military talent. The relations between Turks and Armenians became so poisoned only in the 19th century when the Turks, scared by the emancipation of the Balkan provinces from their crumbling empire, feared a similar Armenian action ${ }^{4}$ and begun to cultivate a Panturkism which was just as insane and murderous as German Pangermanism.

But even at the time of the Turkish massakers (1894 and 1915) a large part of the Ottoman bureaucracy, especially in the lower ranks, was still Armenian. For similar reasons of literacy also a considerable part of this bureaucracy was Greek ${ }^{5}$.

In the different Russo-Turkish wars of the 19th century the Russians acquired a smaller part of Armenia around Erivan, the Russian part became a Soviet Republic in 1920 and is now with 3,5 millions inhabitants the largest Armenian agglomeration of the world. The next largest numbers of Armenians are found in the USA (500000) and in Syria and Lebanon (250000). 
The remaining two millions live in numerous other countries ${ }^{6}$. The Russians submit their Armenian subjects to the same limitations as all their subjects, but unlike the Turks, let them survive and develop. Russian Armenia is flourishing while Turkish "Armenia" is desertlike. Thus it is not surprising that Armenians usually prefer the former to the latter.

The Armenian diaspora was first voluntary. Numerous enterprising young men left the not very fertile mountainous regions even before they were faced with the alternative: conversion or death. Like the Jews before 70 $\mathrm{AD}$ they settled in the ports around the Black or Caspian sea or in great cities like Rome or Byzantium or in Persia or Syria. But from century to century the immigration became more numerous and resembled flight. Masses emigrated after the end of the Bagratid dynasty (1080) and after the end of the Cilician kingdom (1375). They were invited in the 14th century by the far sighted kings of Poland, as they were advantageously known for their literacy, their abilities as craftsmen (especially textile, jewelry) or honest bankers with far reaching international relations. The same kings invited about the same time for the same reason, that is for modernising their country of illiterate peasants, the German Jews ${ }^{7}$. Today, after the massacres of 1915 the majority of Armenians lives in the diaspora. The recent wars in Cyprus and Lebanon have brought them new sufferings.

In what fields did the diaspora Armenians become famous? There is above all the military field. Armenian generals existed probably as far back as Cyrus. Numerous were the Armenian generals in the Byzantine Army. Prokop mentions 16 . We name here only the famous Narses (475-573). The Armenian diaspora in India provided high officers for the British! There were a few Armenian generals even in the Ottoman army, not to speak of the russian armies: in the Zarist (Bagration, Babutow, Melikow etc.) as well as in the bolschewik army. In World War II were noticed an Armenian Marshall: Barghranian, an Airmarshall, an admiral and about 50 generals with Armenian names in the Red Army ${ }^{8}$. And even one of Hitler's best generals had an Armenian name (Guderian).

We have already mentioned Armenians in Ottoman bureaucracy including the army. They filled there in general the lower ranks but some rose to ministerial positions. The same happened in Egypt and Persia. After the Bolschewik revolution at least 10 Armenian "old party members" attained ministerial rank, to begin with the diplomate Karakhan. They were all killed in Stalin's purges in the 1930's, except Anastas Mikojan, the older brother of the MIG constructor Artyom Mikojan. 
Armenians had, as mentioned already, a high reputation as craftsmen, especially in jewelry and weaving ${ }^{9}$. They introduced printing and photography in Asia minor. J. Althen of Avignon promoted dying. Armenia is filled with remarkable ruins, mostly of churches. It is typical that when the Haghia Sophia in Istanbul became defect through an earthquake in 989, it was an Armenian architect Tirdate, who was called to direct the repairs ${ }^{10}$.

Like the Jews, Armenians have become famous as bankers, industrialists or businessmen. Some of the richest men of our time (e. g. Gulbenkian, the oilman; K.Kerkorian, A.Manoogian, E.Mardigian) wear Armenian names. Armenians were also frequently popular doctors or lawyers. But none reached fame there through a discovery. Thus it seems rather an accident that the famous Baglivi (1668-1706) was of Armenian extraction ${ }^{11}$.

Armenians (mostly priests, like with the Jews) were erudite people especially outside of Armenia. There they had been, of course, mostly peasants. They did much for learning and education. The famous Armenian order founded by the Armenian monk Mechitar in 1701 (with its main centers now in Venice and Vienna) so much liked by Byron, played an important role in the spread of scholarship. In a recent USA poll of the diaspora groups the Armenian showed the highest percentage of learned professions like doctors or lawyers and the lowest in divorcing and criminality ${ }^{12}$. The Armenians seem to have had always an inclination towards music as shows the collection of their folk music by Komitas ${ }^{13}$. In today's Western music they play quite a role with e. g. composers like Khatchaturian or Hovhaness, singers like Aznavour, S. Ghazardian or C.Berberian, the violinist M.Parikian or the guitarist J.Byzantine. They rapidly played a great role in new media like the movies (R. Mamoulian!) or television etc. They have produced an extensive literature in their own language, but none of this has acquired status in Western literature. Yet a number of Western writers; e.g. Michel Arlen (recte Kujumdjan) sen. and jun., Saroyan, Henri Troyat (Tarossian) are of Armenian extraction. And it is surprising how many Armenians appear in Western fiction (see R.G. Hovannissian: The Armenian Image in History and Literature, Malibu 1981). Darell has claimed that he is but a pupil of C. Zarian.

Armenians have not been as outstanding in painting as in music. They have nevertheless produced such internationally respected and original artists as Chahine, Arshile Gorky, M.Sarjan, Carzou or Jansem ${ }^{14}$.

The best history of English literature in French was authored by L. Cazamian of the Sorbonne. J. Barzun is a famous US essayist. 
If one compares the diaspora accomplishments of the Jewish and the Armenian group, it is quite striking that both have achieved much as bankers, industrialists or merchants, and harvested corresponding hostilities. The same hold also good to a minor degree for politics. It is advisable to remember here H. Lüthy's statement on French protestant bankers ${ }^{15}$ which seems valid for all minorities (or "marginal" groups). "He filled the functions which society abandoned to him." Also the multilingual character of most minorities certainly played a great role in their fate.

Surprising is the traditional success of Armenians as generals (not paralleled by the Jews, but by e.g. generals with French names who were frequent in the Prussian armies in the 18th and following centuries).

In exchange Armenians did not show the explosion of creativity in science and medicine, which the Jews developed in the 19th century. The Armenian doctors were always numerous and able like the Jewish medieval doctors ${ }^{16}$ but, like all medieval doctors, mostly compilers or translators, not creators. Only in the 20th century some really outstanding Armenian doctors like the Harvard surgeon Kazanjan or Drs. Nasarjan and Damadian have appeared $^{17}$. It should in this context not be overlooked that the Jewish creativity falls only in the post ghetto period, when the Jews lived in a modern society, while the Armenians lived mostly in medieval environments up to the 20 th century. It seems also possible that the difference in numbers-one should not forget the quantitative superiority of the Jewish diaspora (1914: 13.5 millions Jews as compared to 4.5 millions Armenians) - or the difference in religion between the two groups contributed to this situation.

The Armenians have not produced a Henle or Ehrlich, a Broca or Monod, a Hodgkin or Lister, but there is no doubt about the cultural contribution of the Bagration, Melikow, Tiridate, Kasparow, Mechitar, Arlen, Troyat, Sarojan, Aznavour, Katchaturian and many others.

\section{Footnotes}

1 Ackerknecht E. H.: German Jews, English Dissenters, French Protestants. 19th century Pioneers of Modern Medicine and Science. In: Healing and History, ed.Ch. Rosenberg, New York 1979, p.94.

2 De Morgan J.: Histoire du peuple Arménien. Paris 1919.

Bauer E.: Armenien. Luzern 1977.

Walker Chr. J.: Armenia. New York 1980. 
id. with Lang D. M.: Die Armenier. Oldenbourg 1955.

Lang D. M.: The Armenian people in exile. London 1981.

Bartholomaeus L.: In jedem Kreuz ein Lebensbaum. Köln 1956.

Der Nerzessian: The Armenians. London 1969.

3 De Morgan, l.c. p. $280 \mathrm{ff}$.

4. Bartholomaeus, l.c. p. 145; De Morgan, l.c. p. $240 \mathrm{ff}$.

Krikorian: Armenians in the service of the Ottoman Empire. London 1978.

5 Krikorian, l.c. p. 108.

6 Walker and Lang, l.c. p. 18.

7 De Morgan, l.c. p. $291 \mathrm{ff}$.

8 Walker 1980, l.c. p.384-421.

9 Bauer E., l.c. p. 146; De Morgan, l.c. p. 346.

10 Lang D. M., p. 54, 62.

Der Nerzessian, l.c. p. $97-116$.

11 Enezian G.M: Les connaissances médicopharmacologiques à travers les manuscripts Arméniens. Rheinfelden 1982.

12 Bauer E., l.c. p. 49, 172.

13 Bartholomaeus, l.c. p. 198.

14 Mikaeljan M.: Gemäldegalerie Armeniens. Leningrad 1984.

15 Lüthy H.: La banque protestante en France. Paris 1959, vol.I, p. 90.

16 Ackerknecht E.H.: Jüdische Ärzte als Gestalter der Weltmedizin. Gesnerus 38 (1981) $137 \mathrm{ff}$.

17 Lang 1981, l.c. p. 125.

\section{Zusammenfassung}

Die Armenier sind wohl nach den Juden die bekannteste in der Diaspora lebende Minorität. Sie haben ihren Holokaust schon 1915 von den Händen der Türken und Kurden erfahren. Wie haben sie nun beruflich auf das Diasporaschicksal reagiert? Wie die Juden haben sie eine große Rolle in Handel und Industrie gespielt und waren berühmt für ihre Gelehrsamkeit und handwerkliches Geschick. Während aber die Juden bekanntlich eine große Zahl erfinderischer Ärzte und Wissenschaftler hervorbrachten, haben die Armenier zwar viel angesehene, aber bis vor kurzem keine erfinderischen Ärzte produziert. Dafür zeichneten sich die Armenier mindestens seit den Byzantinern als militärische Führer, Generäle, aus; z.B. hatte noch im letzten Weltkrieg die russische Armee über 50 Generäle und mehrere Marschälle armenischen Namens. Sie waren seit je begabte Musiker. Ihre Literatur ist kaum übersetzt, aber zahlreiche angesehene angelsächsische und französische Schriftsteller sind armenischen Ursprungs.

Prof. Dr. med. Dr. med.h.c. mult. Erwin H. Ackerknecht

Ottikerstrasse 42

CH-8006 Zürich 